\title{
Toxic effects of endosulfan on cholesterol levels of liver, brain and gills of stinging catfish, $\mathrm{H}$ eteropneustes fossilis
}

\author{
Sudhish Chandra \\ P.G. Department of Zoology, B.S.N.V. College, Lucknow- 226001, INDIA \\ E-mail: sudhish1953@gmail.com
}

\begin{abstract}
Stinging catfish Heteropneustes fossilis exposed to different concentrations of an organochlorine pesticide endosulfan under static conditions, revealed statistically significant increase in cholesterol contents of liver, brain and gill tissues even at the lowest concentration $(0.0010 \mathrm{mg} / \mathrm{l})$. Fish also elicited behavioral changes due to pesticide toxicity. Hypercholesterolemia appeared to be due to stress induced metabolic alterations caused by intoxication.
\end{abstract}

Keywords: Endosulfan, Toxicity, Hypercholesterolemia, Behavioral alterations

\section{INTRODUCTION}

Pollutants such as pesticides are known to alter the behavioral pattern, growth, reproduction and resistance to diseases of aquatic organism, affecting on a variety of biochemical and physiological mechanism (Geraldine et al., 1999). Organochlorine pesticides are still used for crop protection in several countries without considering their toxic effects on aquatic life. These pesticides reach in water bodies mainly through run-off from agricultural fields and affect the life of non-target organisms like fishes, which are more susceptible than invertebrates (Schocttiger, 1970; and Tandon and Dubey, 1983). Endosulfan is a non-systemic insecticide and is commonly used for agricultural purposes, forestry and gardening. Cholesterol is an important component of great significance in living systems. It holds a key and central position in the metabolism of many closely related biologically important compounds (Shell, 1961), precursor of steroid hormones (Lehninger, 1975) and an important constituent of cell membrane where it modulates their fluidity, fragility and consequently the membrane function (Suhail et al., 1988). Present paper embodies observations on toxic effects of endosulfan on cholesterol contents of liver, brain and gill tissues of freshwater stinging catfish Heteropneustes fossilis, an active and hardy fish of economic importance and has a great demand because of its medicinal value (Talwar and Jhingran, 1991; and Daniels, 2000).

\section{MATERIALS AND METHODS}

Live H eteropneustes fossilis obtained from river Gomti at Lucknow were transported and acclimatized to the laboratory environment, as described earlier (Chandra, 1988). Only healthy looking and active fishes of weight range 100-150 grams were selected for the experiment. They were properly fed and then starved for 24 hours before the experiment. Fish from the same group kept under normal conditions, were used as control. The recommendations made by Doudoroff et al. (1951) and APHA (1992) were followed for the static bioassay tests. The pesticide concentrations, selected on the basis of 80-100\% survival of fishes (Table I). Fish were exposed to different concentrations of pesticide from 24 to 96 hours depending upon their survival at the particular concentration. Fish were taken out regularly after every 24 hours interval from the experimental as well as from control group and washed with distilled water. Their liver, brain and gill were dissected out, washed and kept in $0.7 \%$ cold saline solution. $2.5 \%$ homogenates were prepared in glacial acetic acid and cholesterol level was estimated following method of Rosenthol et al. (1957), using Bausch and Lomb Spectronic - 20 spectrophotometer at $560 \mathrm{~nm}$. The physicochemical characteristics of dechlorinated tap water during the experiment were- temperature $19-21{ }^{\circ} \mathrm{C}$; $\mathrm{pH}$ 7.0-7.4; dissolved oxygen 7.2-7.6 mg/l; total alkalinity 108-115 $\mathrm{mg} / \mathrm{l}$; and total hardness $118-128 \mathrm{mg} / \mathrm{l}$.

\section{RESULTS}

The effects of endosulfan toxicity on cholesterol levels in liver, brain and gill tissues are summarized in Table 2 . At the lowest concentration of $0.0010 \mathrm{mg} / \mathrm{l}$ the cholesterol levels in liver, brain and gill increased continuously upto 72 hours of pesticide exposure and then decreased after 96 hours but remained still above their respective control levels. At $0.0015 \mathrm{mg} / 1,0.0020 \mathrm{mg} / \mathrm{l}$ and $0.0025 \mathrm{mg} / \mathrm{l}$ pesticide concentration the cholesterol levels in liver and brain rose continuously until the terminal hours of exposure. 
Table 1. Percent survival of fishes* in endosulfan activity.

\begin{tabular}{lccccc}
\hline Pesticide & \multicolumn{5}{c}{ Time of exposure in hours } \\
\cline { 2 - 6 } conc. mg/l & 24 & 48 & 72 & 96 & 120 \\
\hline Control & $100 \%$ & $100 \%$ & $100 \%$ & $100 \%$ & $100 \%$ \\
0.0010 & $100 \%$ & $100 \%$ & $90 \%$ & $80 \%$ & $45 \%$ \\
0.0015 & $100 \%$ & $90 \%$ & $80 \%$ & $40 \%$ & $20 \%$ \\
0.0020 & $100 \%$ & $80 \%$ & $50 \%$ & $10 \%$ & $00 \%$ \\
0.0025 & $80 \%$ & $30 \%$ & $10 \%$ & $00 \%$ & $00 \%$ \\
\hline
\end{tabular}

* No. of observations-20 for determining \% survival.

In gills the cholesterol contents increased upto 48 hours of toxicant exposure at $0.0015 \mathrm{mg} / \mathrm{l}$ concentration and then declined. However, with increasing concentration of pesticide, cholesterol levels of gills increased during initial exposure period but later decreased. Interestingly the maximal rise in cholesterol level during the experiment was observed in gills (36.09\%), followed by brain $(29.65 \%)$ and liver $(27.07 \%)$ at $0.0015 \mathrm{mg} / \mathrm{l}$ concentration. Elevated cholesterol contents in liver, brain and gills due to toxic effect of endosulfan were statistically significant $(\mathrm{P}<0.01)$ as compared to their respective control levels. Endosulfan also produced behavioral changes in $H$.fossilis such as convulsions which were more frequent during the terminal hours of experiment, rapid air gulping, copious mucus secretion, loss of balance and sensitivity to touch and sound.

\section{DISCUSSION}

The toxicants on entering into fish body cause deleterious effects on functional activity of endocrine system and metabolism leading to physiological, pathological and biochemical disorders (Bais and Arasta, 1995; Arasta et al., 1999, Pandey et al., 2000;
Karuppasamy 2002; David et al., 2003). Certain pathological informations along with physiological and biochemical data may provide accurate and early indication of toxicity of organochlorine pesticide (Krishnagopal et al., 1988). Endosulfan had significantly increased cholesterol levels of liver, brain and gill tissues of $\mathrm{H}$.fossilis at all concentrations in these experiments. It was further observed that the rate of increase in cholesterol was higher in the initial period of pesticide exposure to fishes but following prolonged exposure the same was much lower. However, the level remained above the control level. Lipids provide an essential, readily available energy source for fish, of which cholesterol is of major importance because of its relationship to many physiologically active steroids and hormones (Tiez, 1970; Evans, 1998). Alterations in cholesterol level may be an indirect result of toxicant effect on metabolic enzymes (Mayer et al., 1992; Padmini et al., 2004). Marked biochemical alterations in blood and tissues of freshwater cat fish H.fossilis have been reported by Singh and Srivastava (1998) and Chandra (2008) following formothion and malathion exposure. Biochemical changes are primarily due to shift in the respiratory metabolism caused by pesticide in the ambient environment and utilization of organic reserves yielding excess energy to compensate the stress. Toxic stress to fish $\mathrm{H}$.fossilis was quite evident in these experiments showing abnormal behavioral changes. Rao et al. (1981) reported reduced oxygen consumption in fish M.aculeatum treated with endosulfan. Exposure to sublethal concentration of thiodon lead to $40 \%$ decline in oxygen consumption rate in Mystus vittatus (Reddy and Gonathy, 1977). Varied respiratory response may occur in fishes (Thosar and

Table 2. Cholesterol levels of different tissues of $\mathrm{H}$.fossilis following endosulfan toxicity.

\begin{tabular}{|c|c|c|c|c|}
\hline \multirow[t]{3}{*}{$\begin{array}{l}\text { Pesticide conc. } \\
\mathrm{mg} / \mathrm{l}\end{array}$} & \multicolumn{4}{|c|}{$\begin{array}{l}\text { Cholester ol mg./100mg. Fresh weight } \\
\text { M ean } \pm \text { Std. deviation }\end{array}$} \\
\hline & \multicolumn{4}{|c|}{ Time of exposure in hours } \\
\hline & 24 & 48 & 72 & 96 \\
\hline & \multicolumn{4}{|c|}{ Liver - Control $-2.29 \pm 0.12$} \\
\hline 0.0010 & $2.62 \pm 0.13$ & $2.80 \pm 0.17$ & $2.85 \pm 0.30$ & $2.60 \pm 0.30$ \\
\hline 0.0015 & $2.80 \pm 0.16$ & $2.98 \pm 0.15$ & $3.14 \pm 0.32$ & \\
\hline 0.0020 & $3.04 \pm 0.42$ & $3.10 \pm 0.24$ & & \\
\hline \multirow[t]{2}{*}{0.0025} & $3.00 \pm 0.25$ & & & \\
\hline & \multicolumn{4}{|c|}{ B rain -Control- $2.80 \pm 0.08$} \\
\hline 0.0010 & $3.27 \pm 0.17$ & $3.46 \pm 0.24$ & $3.70 \pm 0.23$ & $3.40 \pm 0.42$ \\
\hline 0.0015 & $3.40 \pm 0.38$ & $3.66 \pm 0.30$ & $3.98 \pm 0.31$ & \\
\hline 0.0020 & $3.60 \pm 0.28$ & $3.84 \pm 0.42$ & & \\
\hline \multirow[t]{2}{*}{0.0025} & $3.37 \pm 0.38$ & & & \\
\hline & \multicolumn{4}{|c|}{ Gills-Control-1.08 \pm 0.10} \\
\hline 0.0010 & $1.28 \pm 0.13$ & $1.35 \pm 0.08$ & $1.40 \pm 0.06$ & $1.20 \pm 0.12$ \\
\hline 0.0015 & $1.39 \pm 0.08$ & $1.69 \pm 0.12$ & $1.46 \pm 0.28$ & \\
\hline 0.0020 & $1.48 \pm 0.19$ & $1.60 \pm 0.21$ & & \\
\hline 0.0025 & $1.22 \pm 0.25$ & & & \\
\hline
\end{tabular}


Lonker, 2004) depending upon exposure period of toxicant, stress and the intensity of damage caused to gills. Further dose dependent behavioral changes in fish $H$.fossilis clearly indicated stages of stress response, the alarm reaction, the state of resistance and the stage of exhaustion in present experiment. It appeared that fishes exposed to lowest concentration of pesticide did not reach upto the state of exhaustion, rather they were able to accommodate and adapt the stress. However, fishes exposed to higher concentration of endosulfan could not resist the stress for longer duration and died. Nath (2003) also reported abnormal behavior in Clarias batrachus, $H$ eteropneustes fossilis and Labeo rohita of wetland pond of Bihar, contaminated with endosulfan. Matsmura (1980) reported that susceptibility and survival time in fishes are directly related to body size, weight and age in ambient environment. Deshmukh and Sonawane (2007) reported significant changes is blood corpuscles number and attributed as an adaptation to meet stressful condition in the fish Channa gachua following long term exposure to endosulfan. Chandra et al. (2007) reported significant increase in Glutamic oxalacetic and pyruvic transaminase in brain and liver of $\mathrm{C}$. batrachus due to toxicity of malathion and dimicron pesticides which indicated impaired carbohydrate and protein metabolism. Aldolase, an important gluconeogenic enzyme which plays an essential role in mobilization of energy to tolerate additional stress, was also reported to escalate significantly in liver, brain and gill of $\mathrm{C}$. batrachus, following pesticide exposure (Chandra, 2010). Such biochemical changes clearly indicated utilization of organic reserves yielding excess energy to cope up the toxic stress of environment at their level best.

Since cholesterol plays an important role in body metabolism and being associated with almost every organ of body, was the foremost biochemical component of tissues revealing significant alterations in present observations. The percentage elevation of cholesterol were noted to be higher during early period of exposure to toxicant than prolonged one, which suggested that the fish tried its best to accommodate with the situation and doing so body metabolism became rapid to fulfil energy requirement, utilizing organic reserves, yielding excess energy to compensate the toxic stress. The mobilization of energy substances as secondary response and reduced capacity to tolerate additional stress have been described as a part of integrated response in fish (Bonga, 1997). Increased glucose contents in brain of H.fossilis (Shrivastava et al., 2002) and changes in liver cholesterol have been observed following exposure of fish to various pollutants (Kasthuri and Chandran, 1997; and Kulkarni and Dharmadhker, 1998). Gills being the primary sites of absorption but having poor drug metabolizing capacity, indicated maximum rise (36.09\%) in cholesterol level. Endosulfan toxicity have also been reported to cause degeneration, necrosis, hyperplasia and hypertrophy in gills, liver and muscle tissues (Kumar et al., 2000; and Sharma et al., 2001). These observations further support the decreasing cholesterol levels in liver, brain and gill tissues of $\mathrm{H}$.fossilis following prolonged exposure and increasing doses to pesticide when fish became exhausted. Thus it can be concluded that even very low concentration of endosulfan pesticide significantly altered cholesterol level of fish H.fossilis and behavioral changes are the early symptoms to gauge the potential toxicity of a toxicant.

\section{REFERENCES}

APHA (1992). Standard methods for the examination of water and Waste water, $17^{\text {th }}$ ed. American Public Health Association, Washington DC.

Arasta, T., Bais, V.S. and Thakur, P.B. (1999). Changes is selected biochemical parameters in the liver and muscles of fish Mystus vittatus exposed to aldrin. In Environment Pollution Mangement. Creative Pub. Sagar PP-109-112.

Bais, V.S. and Arasta, T. (1995). Effect of sublethal concentration of Aldex on protein, lipid and glycogen levels in the liver and muscles of a catfish Mystus vittatus J. Freshwat Biol 7:151-154.

Bonga, S.E.W. (1997). The stress response in fish. Physiol, Rew., 77:591-625.

Chandra, S. (1988). Effect of malathion on the cholesterol levels of different tissues of fresh water catfish Clarias batrachus., J. Rec. Adv. Appl. Sc. 3:50-503.

Chandra S. (2008). Toxic effect of Malathion on acetylcholinesterase activity of liver, brain and gills of freshwater catfish $\mathrm{H}$ eteropneustes fossilis. Environ. Conserv. J., 9:47-52.

Chandra, S. (2010). Impact of Rogor toxicity on aldolase and acetylcholinesterase activity in liver, brain and gills of freshwater catfish Clarias batrachus. Rec. Adv. Fish Ecol. Limn. Ecoconserv. 8:165-175.

Chandra S., Bajpai, N.K. and Dubey, A. (2007). Pesticide induced changes is the activity of transaminases in tissues of freshwater catfish Clarias batrachus. Rec. Adv. Fish. E col. Limn. Ecoconserv., 7:143-149.

Daniels, R.J.(2000). Freshwater fishes of Peninsular India. Ind. Acad. Sci. Univ. Press Pvt. L td., N ew D elhi.

David, M., Mushiger, S.B., Prashant, M.S. and Mathad, S.G. (2003). Hepatotoxicity of Malathion on protein metabolism in Catla catla. Adv. Biol., 22:115-120.

Deshmukh, D.R. and Sonawane, S.R. (2007). Effect of long term exposure to endosulfan on blood cell count in Channa gachua. J . Indian Fish Assoc., 34:83-85.

Doudoroff, P., Anderson, B.G., Burdick, G.E., Galtsof, P.S., Hart, W.B., Patric, R., Strong, E.R., Surber, E.W. and Vanhorn, W.M. (1951). Bioassay methods for the evaluation of acute toxicity of industrial wastes to fish. Sewage Ind. Wastes, 23: 1380-1397.

Evans, D.H. (1998). The physiology of fishes, $2^{\text {nd }}$ ed. C.R.C. Press, Boca, N. York.

Geraldine, P., Bhavan, P.S., Kaliamurthy, J. and 
Zayapragassarazan, Z. (1999). Effect of dichlorv intoxication in the freshwater prawn Macrobrachium malcolmsoni. J . Environ. Biol., 20:141-148.

Karuppasamy, R. (2002). Short and long term effect of phenyl mercuric. acelate on protein metabolism in Channa punctatus. J. Natcon., 12: 83-93.

Kasthuri, J. and Chandran, M.R. (1997). Sublethal effect of lead on feeding, energetics growth performance, biochemical composition and accumulation in the eusturine catfish M ystus gulia. J. Env. Biol., 18:95-101.

Krishnagopal, Ram, M.D., Gupta, G.S.D. and Anand, M. (1988). Lindane induced histological changes in the gills of Channa punctatus. Ind. J. Bioresearch., 8:25-29.

Kulkarni, G.P.P. and Sunita Dharmadhker, M.(1998). Effect of dairy effluents on biochemical parameters of wheat seed and fish. Proc. Acad. Environ. Biol. 7:57-60.

Kumar, S., Lata, S. and Krishnagopal (2000). Histopathological changes in gills of Heteropneustes fossilis, induced by Deltamethrin. Proc. Acad. Environ. Biol., 9:171-173.

Lehninger, A.L. (1975). Biochemistry, $2^{\text {nd }}$ ed. Werth Publ. Inc., New Work.

Matsmura, F. (1980). Toxicity of Insecticides. Plenum P ress, London.

Mayer, F.L.,Versteeg, D.J. and Rattner, B.A. (1992). Biomarkers - Physiological and histological markers of anthropogenic stress. Proc. Viii Pelston Workshop, Lewis Pub. U.S.A.

Nath, A., (2003). Bioaccumulation of various pesticides in fish muscle.). E cophysiol. O ccup. H Ith., 1:40-46

Padmini, E., Thendral Hepsibha, B. and Santhalin Shellomith, A.S. (2004). Lipid alteration as stress markers in grey mullets Mugil cephalus caused by industrial effluents in Ennore eustury. Aquacult., 5:115-118.

Pandey, A.C., Krishnagopal and Pandey, A.K. (2000). Pollution and fish physiology. Aquacult., 1:1-8.

Rao, D.M.R., Dani., A.M. and Murthy, A.S. (1981). Toxicity and metabolism of endosulfan and its effect on oxygen consumption and total nitrogen excretion of the fish
M acrognathus aculeatum. Pestic, Biochem. Physiol., 15:282 287.

Reddy, T.G. and Gonathy, S. (1977). Toxicity and respiratory effect on catfish M ystus vittatus, Ind. J . Env. H Ith., 19:360363.

Rosenthal, H.L., Pfluke, M.L. and Buscaglia, S. (1957). A stable iron reagent for determination of Cholesterol. J . Lab. Clin. Med., 50:318.

Schocttiger, R.A. (1970). Toxicity of thiodon in several fish and aquatic invertebrates. U.S. dept. Int. Fish. Wildl. Ser v. Rep., 35.

Sharma, R.R., Pandey, A.K. and Shukla, G.R. (2001). Histopathological alterations in fish tissues Induced by pesticides toxicity. Aquacult., 2: 31-43.

Shell, E.W. (1961). Chemical composition of blood of small mouthbass. Res. Rep. U.S. Wildl. Serv., 57:1-36.

Shrivastava, S., Singh, S. and Shrivastava, K. (2002). Effect of carbaryl on glucose content in the brain of H eter opneustes fossilis. J . E cotoxicol. Environ. M onit., 12:205-208.

Singh, N.N. and Srivastava, A.K.(1998). Formothion induced biochemical changes in blood and tissues of freshwater catfish H eteropneustes fossilis. M alys. Appl. Biol., 27:39-43

Suhail, M., Athar, J. and Rizvi, S.I. (1988). Lipid changes in red cell membrane in leukemia., Ind. J. Med. Res., 88:350355.

Talwar, P.K. and Jhingran, R.J. (1991). Inland Fishes. vol. 2, Oxford \& IBH Pub. Co. Pvt. Ltd., India.

Tandon, R.S. and Dubey, A. (1983). Toxic effects of two organophosphorus pesticides on Fructose 1,6, diphosphate Aldolase activity of liver, brain and gills of the freshwater fish Clarias batrachus. Envir on. Pollut., 31:1-7.

Thosar, M.R. and Lonker, A.N. (2004). Respiratory response of male fish Labestes reticulatus exposed to sublethal concentration of insecticide Metasystox., J. Ecol. Occup. HIth., 4:62-67.

Tiez., N.W. (1970). Fundamentals of clinical chemistry, W.B. Saunders C 0., USA. 